\title{
Different Policy Measures and Practices between Swedish Counties Influence Market Dynamics: Part 1-Biosimilar and Originator Infliximab in the Hospital Setting
}

\author{
Evelien Moorkens ${ }^{1} @ \cdot$ Steven Simoens ${ }^{1} \cdot$ Per Troein $^{2} \cdot$ Paul Declerck $^{1} \cdot$ Arnold G. Vulto $^{1,3} \cdot$ Isabelle Huys $^{1}$
}

Published online: 3 April 2019

(c) The Author(s) 2019

\begin{abstract}
Background Decentralisation of healthcare budgets and issuance of local guidelines means that the use of biosimilars can vary by region within a particular country, for example between the 21 counties of Sweden.

Objectives This study aimed to analyse the county-level market dynamics of biosimilar and originator infliximab, which are hospital products, and to examine how local policy measures and practices, in addition to national policy, influenced market dynamics. Methods We first conducted a literature review on (biosimilar) policies in Sweden, then analysed market data provided by IQVIA $^{\mathrm{TM}}$ on uptake of originator and biosimilar infliximab within the different counties (Q2 2012 to Q4 2017), including discounts from (tender) contracts. Biosimilar market shares were calculated with volume data (measured as defined daily doses [DDDs]). We then discussed our findings in semi-structured interviews with the national pricing and reimbursement agency, key experts within the county councils of Skåne, Västra Götaland, and Stockholm, and an industry representative. Results Market shares of biosimilar infliximab vary widely between counties (range 18-96\% in 2017). The initial uptake of biosimilar infliximab was slow and variable, with abrupt increments in biosimilar market shares coinciding with expiration of contracts for the originator product. Different approaches taken by counties to achieve a low cost per DDD of infliximab were identified, i.e., a rapid switch to the biosimilar (Skåne), a delayed switch to the biosimilar (Stockholm), or no switch to the biosimilar when a favourable price on the originator product could be obtained (Västra Götaland). Quantitative analysis showed that $59 \%$ of the variability in biosimilar market shares could be explained by the relative difference in discounted price between the biosimilar and the originator product. In addition, qualitative analysis indicated the presence of key opinion leaders, local guidelines and initiatives, and whose budget it affects as drivers in the decision-making process.

Conclusions Variations in the market share of biosimilar infliximab between the Swedish counties is largely explained by the discounted price difference between biosimilar and originator product, and counties used different strategies to leverage such biosimilar competition. Additionally, the presence of key opinion leaders, local guidelines and gainsharing arrangements appeared to play a role in infliximab market dynamics in counties.
\end{abstract}

Arnold G. Vulto and Isabelle Huys: Joint last author.

Arnold G. Vulto

a.vulto@gmail.com

Evelien Moorkens

evelien.moorkens@kuleuven.be

1 Department of Pharmaceutical and Pharmacological Sciences, KU Leuven, Leuven, Belgium

2 IQVIA, Solna, Sweden

3 Hospital Pharmacy, Erasmus University Medical Center, Rotterdam, The Netherlands

\section{Key Points}

Biosimilar infliximab market shares in Swedish counties ranged from 18 to $96 \%$ in 2017.

Variations in the discounted price difference between the biosimilar and originator product, and associated savings, explain variations in biosimilar uptake between counties.

Counties employ different strategies to achieve low costs for treatment with infliximab. 


\section{Introduction}

The advent of biological medicinal products, i.e. medicines produced by or extracted from a biological source, has revolutionised the treatment of many diseases by their specificity to key disease mediators, e.g., tumour necrosis factor (TNF)- $\alpha$, a cytokine involved in the body's inflammatory response [1]. Elevated levels of $\mathrm{TNF} \alpha$ are associated with diseases such as rheumatoid arthritis, psoriatic arthritis, ankylosing spondylitis, psoriasis and inflammatory bowel disease [2]. Therefore, TNF $\alpha$ inhibitors, medicines that block the activity of $\mathrm{TNF} \alpha$, improved the treatment options for these diseases by reducing the inflammatory reaction. Currently, five different molecules have been proven to inhibit the action of TNF $\alpha$ : infliximab, etanercept, adalimumab, certolizumab pegol, and golimumab. In 2017, these molecules had combined global sales of \$US39.8 billion [3].

However, as patents and other exclusivity rights on marketed TNF $\alpha$ inhibitors expire, non-innovator versions, i.e., biosimilars, may enter the market. The introduction of biosimilars may create competition in this class, possibly resulting in lowered prices, and alter market dynamics in disease areas using TNF $\alpha$ inhibitors.

In 2013, the first biosimilar of a TNF $\alpha$ inhibitor, biosimilar infliximab, received marketing authorisation across Europe under the names Inflectra ${ }^{\circledR}$ and Remsima ${ }^{\circledR}$ [4]. Its originator product, Remicade ${ }^{\circledR}$, was then one of the top three-selling biological products in the world [5]. Marketing authorisation for other biosimilars to infliximab followed in 2016 with Flixabi ${ }^{\circledR}$ and in 2018 with Zessly ${ }^{\circledR}$. Etanercept biosimilars Benepali ${ }^{\circledR}$ and Erelzi ${ }^{\circledR}$ received marketing authorisation in 2016 and 2017, respectively. Several biosimilars to Humira ${ }^{\circledR}$ (adalimumab) have also gained marketing authorisation. Market exclusivity rights on the originator product expired in October 2018.

After marketing authorisation is received from the European Commission, it is the responsibility of the Member States to coordinate pricing, reimbursement and subsequent entry of these products to the market. This contributes to variations in the use of biosimilars across Europe [6]. Furthermore, regional differences in the use of medicines can be observed within a country [7-14]; for example, in Sweden, the Health and Medical Services Act of 1982 (updated in 2017) decentralised responsibilities for healthcare budgets and services to the 21 county councils $[15,16]$. It was believed that decentralisation of the drug budget to the county councils would increase cost awareness and improve rational prescribing of medicines [17]. By law, the 21 county councils are required to have a drug and therapeutics committee, which aims to improve rational prescribing of medicines [18]. These drug and therapeutics committees are supported by different therapy groups or expert committees and are responsible for making recommendations on the use of medicines, including advice on purchasing of medicines and education of healthcare professionals [19]. Although legislation, general health policy objectives, and high-level recommendations on healthcare are decided at a national level, other factors (e.g. local tendering, regional recommendations) appear to play a role in the fragmented picture of market access of biosimilars in these counties and may explain regional variations in biosimilar prices and market shares.

The hospital setting (e.g., infliximab) and outpatient setting (e.g., etanercept) are organised differently in Sweden (Fig. 1), providing us the opportunity to distinguish between characteristics of the setting and general driving factors that influence market dynamics. For medicines administered in the hospital setting, public procurement is carried out at the county level. The county councils finance these medicines and provide recommendations on preferred treatments [20]. However, in special cases, the New Therapies Council can make recommendations at a national level to pursue equal treatment between the counties [21]. On the other hand, in the outpatient setting, decisions on pricing and reimbursement of prescription medicines are made by the Dental and Pharmaceutical Benefits Agency, a governmental agency under the Ministry of Health and Social Affairs [22].

The aim of this study was to both quantitatively and qualitatively analyse the market dynamics of biosimilar and originator TNFo inhibitors in Sweden's 21 counties and to examine how local policy measures and practices, in addition to national policy, influence market dynamics between the counties. This article is the first of two and studies regional variations in originator and biosimilar infliximab (hospital setting); the second article will discuss the market dynamics of originator and biosimilar etanercept (outpatient setting) [45].

\section{Methods}

A comparative analysis was performed in three steps: (1) a review of the literature on (biosimilar) policies in Sweden; (2) a comparative analysis of counties' originator and biosimilar infliximab market shares on the one hand, and of policy measures and initiatives at national and county levels on the other hand; and (3) a discussion of findings via followup interviews with key experts in a selection of counties.

\subsection{Literature Review}

The literature review served to describe the main characteristics of the Swedish national healthcare system and policies on biosimilars, including county-level policy measures and initiatives. We searched PubMed to the end of November 


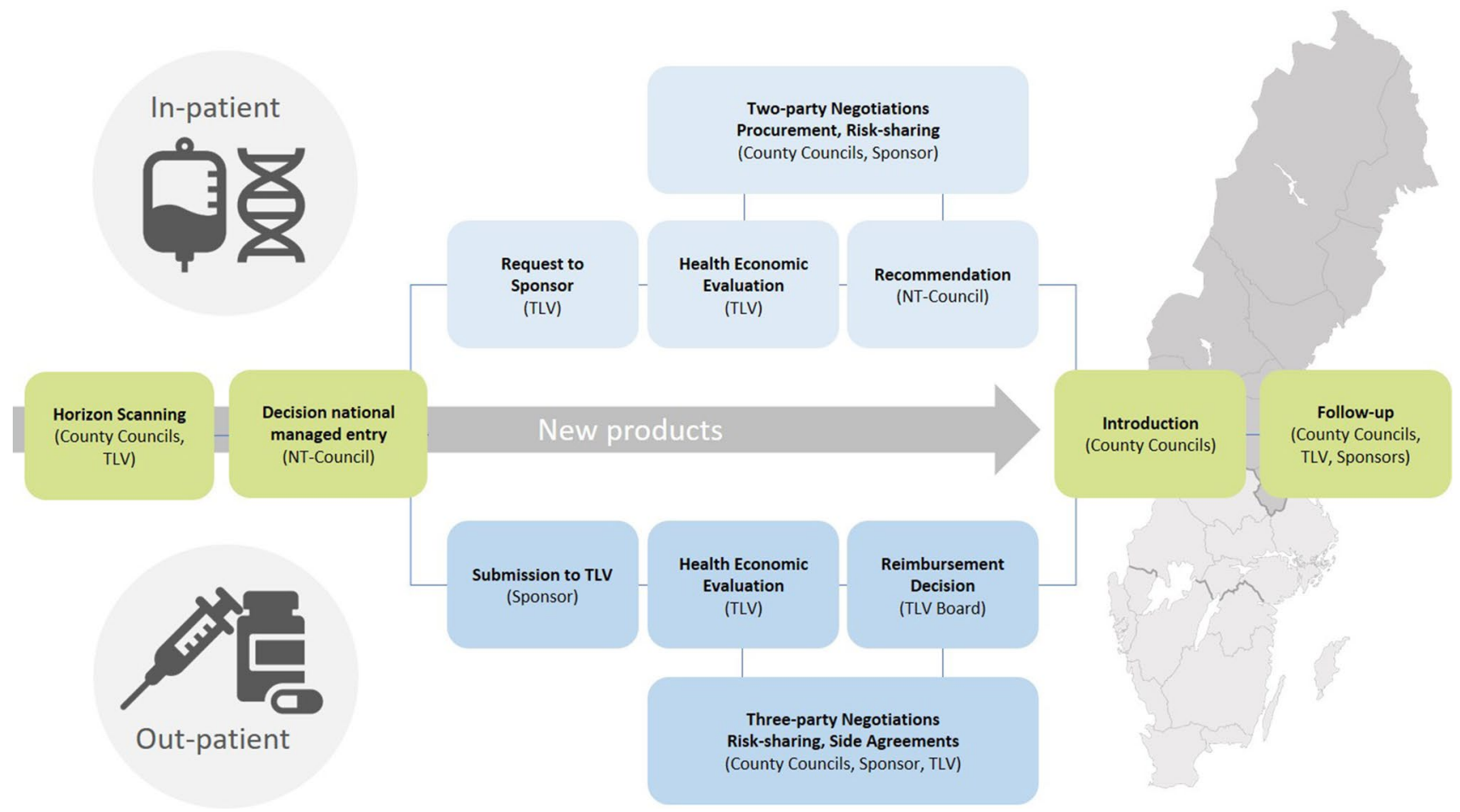

Fig. 1 Organisation of and key players involved in the hospital (top) and outpatient setting (bottom) in Sweden [44]. Reproduced with permission from Gustaf Befrits. NT-Council New Therapies Council,

2017 by combining search terms on health policy, biosimilars and Sweden. Studies could be published in English, Swedish, or Dutch. We also searched the reference lists of identified articles for other relevant studies. Articles and reports known to the authors were also included. The websites of the county councils and the Dental and Pharmaceutical Benefits Agency served as additional information sources.

\subsection{Analysis of Market Data}

Market data on the uptake of originator and biosimilar infliximab in each county were provided by IQVIA ${ }^{\mathrm{TM}}$, and consisted of units, defined daily doses (DDDs), expenditure based on pharmacies' purchase prices (prices at wholesale level) and expenditure based on discounted prices (hospital products) on different pack sizes of originator and biosimilar infliximab from quarter two of 2012 to quarter four of 2017 [23]. Net expenditure including discounts from (tender) contracts were used to make calculations on discounted prices per DDD. Per county, graphs were drafted to show the evolution in volume (measured as DDDs) and price (measured as discounted price per DDD) over time for each originator and biosimilar product. In this way, the influence of the introduction of a biosimilar TNF $\alpha$ inhibitor (i.e., biosimilar infliximab) on the originator product could be studied in the
TLV Tandvårds- och läkemedelsförmånsverket (Dental and Pharmaceutical Benefits Agency)

context of existing policy measures. Biosimilar market shares (calculated as volume of biosimilars over volume of biosimilars and originator product) were also determined over time for the different counties. Economic theory suggests that a lower price will lead to increased uptake of a product. Therefore, we conducted a simple regression analysis using SPSS software [24] to test how much of the variation in biosimilar market shares between the counties could be explained by the relative difference in discounted price between the biosimilar and the originator product. A level of significance of 0.05 was adopted. Data for 2017 were used in the analysis rather than only quarter four of 2017 (most recent data), since the data set for 2017 showed more variation in biosimilar market shares (2017: 18-96\% vs. Q4 2017: 23-94\% biosimilar market share). Data from earlier than 2017 were not analysed because they might reflect a still-developing market. We assumed that the prevalence of conditions for which TNF $\alpha$ inhibitors were used was the same in all counties [7]. Various multiple regression models were used to study the relation between the biosimilar market share and various covariates, including the number of inhabitants per county, the number of inhabitants per procurement group, the presence of an academic hospital, the discounted price per DDD of infliximab/ biosimilar/originator, the relative/absolute difference in discounted price between the biosimilar and originator product, and the geographical location. Models were compared using 
the adjusted determination coefficient $\left(R^{2}\right)$, accounting for multicollinearity and the authors' knowledge of the Swedish healthcare system.

\subsection{Interviews}

We conducted follow-up interviews with local correspondents to discuss the results of the comparative analysis and to gain more in-depth information to add to the analysis. First, discussions were held with the national pricing and reimbursement agency (The Dental and Pharmaceutical Benefits Agency) and one county council (Stockholm). Subsequently, local interviews were conducted with five county representatives in Skåne, Västra Götaland, and Stockholm. These counties were selected based on previous analysis of literature and market data; combined, they represent $>50 \%$ of the Swedish population. County councils were contacted via email or telephone to ask whether they could refer us to their biosimilar expert for a discussion on how they approach biosimilars in their county. In addition, one interview was conducted with an industry representative to get a more comprehensive view of market dynamics in the different counties in Sweden. An interview guide was used to structure the interviews. Questions were based upon the comparative analysis of relevant literature and market data and discussions with the national pricing and reimbursement agency and were organised into two topics: general questions on the county's policy on biosimilars and questions on the market data for infliximab.
All interviewees received an email with an informed consent form to ask permission to record the interviews for data analysis. All interviews were conducted face to face in Sweden, in English, in March 2018. The recorded interviews were transcribed ad verbatim, coded, and processed using qualitative analysis. Results from the interviews were verified with the national pricing and reimbursement agency, and any outstanding questions about the Swedish healthcare system and observations during the interviews were further explored.

\section{Results}

\subsection{Market Data for Infliximab in All Counties}

The market share of biosimilar infliximab ranges widely across Sweden (based on volume), from 18\% in Västmanland to $96 \%$ in Gotland in 2017. Table 1 shows biosimilar market shares over time for the different Swedish counties. In quarter four of 2017, two groups of counties can be distinguished: counties with biosimilar market shares of $\geq 70 \%$ and those with market shares of $\leq 50 \%$. Biosimilar market shares over time for the counties show that initial uptake of biosimilar infliximab was slow and varied widely, with abrupt increments in biosimilar market shares. This is due to the procurement mechanism for infliximab, where counties might have initially still been locked into a contract for the originator product, Remicade ${ }^{\circledR}$.

Table 1 Market shares (\%) of biosimilar infliximab over time for the different Swedish counties. Colours gradually change from red to green with increasing biosimilar market shares

\begin{tabular}{|c|c|c|c|c|c|c|c|c|c|c|c|c|}
\hline County & 2015 Q1 & 2015 Q2 & 2015 Q3 & 2015 Q4 & 2016 Q1 & 2016 Q2 & 2016 Q3 & 2016 Q4 & 2017 Q1 & 2017 Q2 & 2017 Q3 & 2017 Q4 \\
\hline Blekinge & $15 \%$ & $23 \%$ & $24 \%$ & $21 \%$ & $23 \%$ & $20 \%$ & $33 \%$ & $59 \%$ & $74 \%$ & $76 \%$ & $76 \%$ & $77 \%$ \\
\hline Dalarna & $0 \%$ & $5 \%$ & $1 \%$ & $6 \%$ & $5 \%$ & $11 \%$ & $12 \%$ & $13 \%$ & $15 \%$ & $34 \%$ & $67 \%$ & $87 \%$ \\
\hline Gävleborg & $0 \%$ & $0 \%$ & $0 \%$ & $2 \%$ & $0 \%$ & $14 \%$ & $5 \%$ & $25 \%$ & $31 \%$ & $42 \%$ & $46 \%$ & $50 \%$ \\
\hline Gotland & $0 \%$ & $0 \%$ & $5 \%$ & $20 \%$ & $4 \%$ & $25 \%$ & $13 \%$ & $21 \%$ & $98 \%$ & $98 \%$ & $96 \%$ & $94 \%$ \\
\hline Halland & $0 \%$ & $8 \%$ & $8 \%$ & $43 \%$ & $66 \%$ & $61 \%$ & $62 \%$ & $66 \%$ & $77 \%$ & $85 \%$ & $84 \%$ & $87 \%$ \\
\hline Jämtland & $0 \%$ & $2 \%$ & $0 \%$ & $7 \%$ & $19 \%$ & $16 \%$ & $13 \%$ & $91 \%$ & $90 \%$ & $85 \%$ & $94 \%$ & $91 \%$ \\
\hline Jönköping & $0 \%$ & $0 \%$ & $1 \%$ & $3 \%$ & $3 \%$ & $3 \%$ & $5 \%$ & $9 \%$ & $37 \%$ & $88 \%$ & $84 \%$ & $90 \%$ \\
\hline Kalmar & $4 \%$ & $9 \%$ & $5 \%$ & $5 \%$ & $5 \%$ & $7 \%$ & $5 \%$ & $8 \%$ & $34 \%$ & $68 \%$ & $66 \%$ & $73 \%$ \\
\hline Kronoberg & $0 \%$ & $6 \%$ & $7 \%$ & $17 \%$ & $36 \%$ & $79 \%$ & $94 \%$ & $84 \%$ & $85 \%$ & $84 \%$ & $82 \%$ & $81 \%$ \\
\hline Norrbotten & $0 \%$ & $1 \%$ & $2 \%$ & $5 \%$ & $11 \%$ & $6 \%$ & $6 \%$ & $59 \%$ & $80 \%$ & $92 \%$ & $91 \%$ & $92 \%$ \\
\hline Örebro & $0 \%$ & $0 \%$ & $6 \%$ & $16 \%$ & $20 \%$ & $39 \%$ & $55 \%$ & $58 \%$ & $62 \%$ & $81 \%$ & $88 \%$ & $89 \%$ \\
\hline Östergötland & $2 \%$ & $6 \%$ & $9 \%$ & $17 \%$ & $14 \%$ & $15 \%$ & $16 \%$ & $23 \%$ & $30 \%$ & $33 \%$ & $33 \%$ & $36 \%$ \\
\hline Skåne & $2 \%$ & $8 \%$ & $19 \%$ & $53 \%$ & $72 \%$ & $84 \%$ & $87 \%$ & $88 \%$ & $89 \%$ & $88 \%$ & $90 \%$ & $92 \%$ \\
\hline Södermanland & $0 \%$ & $1 \%$ & $7 \%$ & $13 \%$ & $30 \%$ & $90 \%$ & $92 \%$ & $91 \%$ & $89 \%$ & $91 \%$ & $90 \%$ & $90 \%$ \\
\hline Stockholm & $0 \%$ & $3 \%$ & $6 \%$ & $17 \%$ & $18 \%$ & $21 \%$ & $23 \%$ & $23 \%$ & $80 \%$ & $84 \%$ & $87 \%$ & $86 \%$ \\
\hline Uppsala & $0 \%$ & $1 \%$ & $1 \%$ & $5 \%$ & $6 \%$ & $7 \%$ & $8 \%$ & $8 \%$ & $16 \%$ & $20 \%$ & $22 \%$ & $25 \%$ \\
\hline Värmland & $1 \%$ & $7 \%$ & $12 \%$ & $23 \%$ & $93 \%$ & $90 \%$ & $89 \%$ & $90 \%$ & $88 \%$ & $89 \%$ & $85 \%$ & $88 \%$ \\
\hline Västerbotten & $0 \%$ & $0 \%$ & $8 \%$ & $7 \%$ & $3 \%$ & $7 \%$ & $8 \%$ & $71 \%$ & $94 \%$ & $90 \%$ & $88 \%$ & $91 \%$ \\
\hline Västernorrland & $0 \%$ & $0 \%$ & $0 \%$ & $5 \%$ & $3 \%$ & $6 \%$ & $12 \%$ & $78 \%$ & $85 \%$ & $86 \%$ & $84 \%$ & $83 \%$ \\
\hline Västmanland & $0 \%$ & $1 \%$ & $4 \%$ & $7 \%$ & $5 \%$ & $5 \%$ & $8 \%$ & $15 \%$ & $16 \%$ & $15 \%$ & $20 \%$ & $23 \%$ \\
\hline Västra Götaland & $0 \%$ & $2 \%$ & $2 \%$ & $9 \%$ & $8 \%$ & $11 \%$ & $10 \%$ & $16 \%$ & $22 \%$ & $41 \%$ & $42 \%$ & $47 \%$ \\
\hline
\end{tabular}




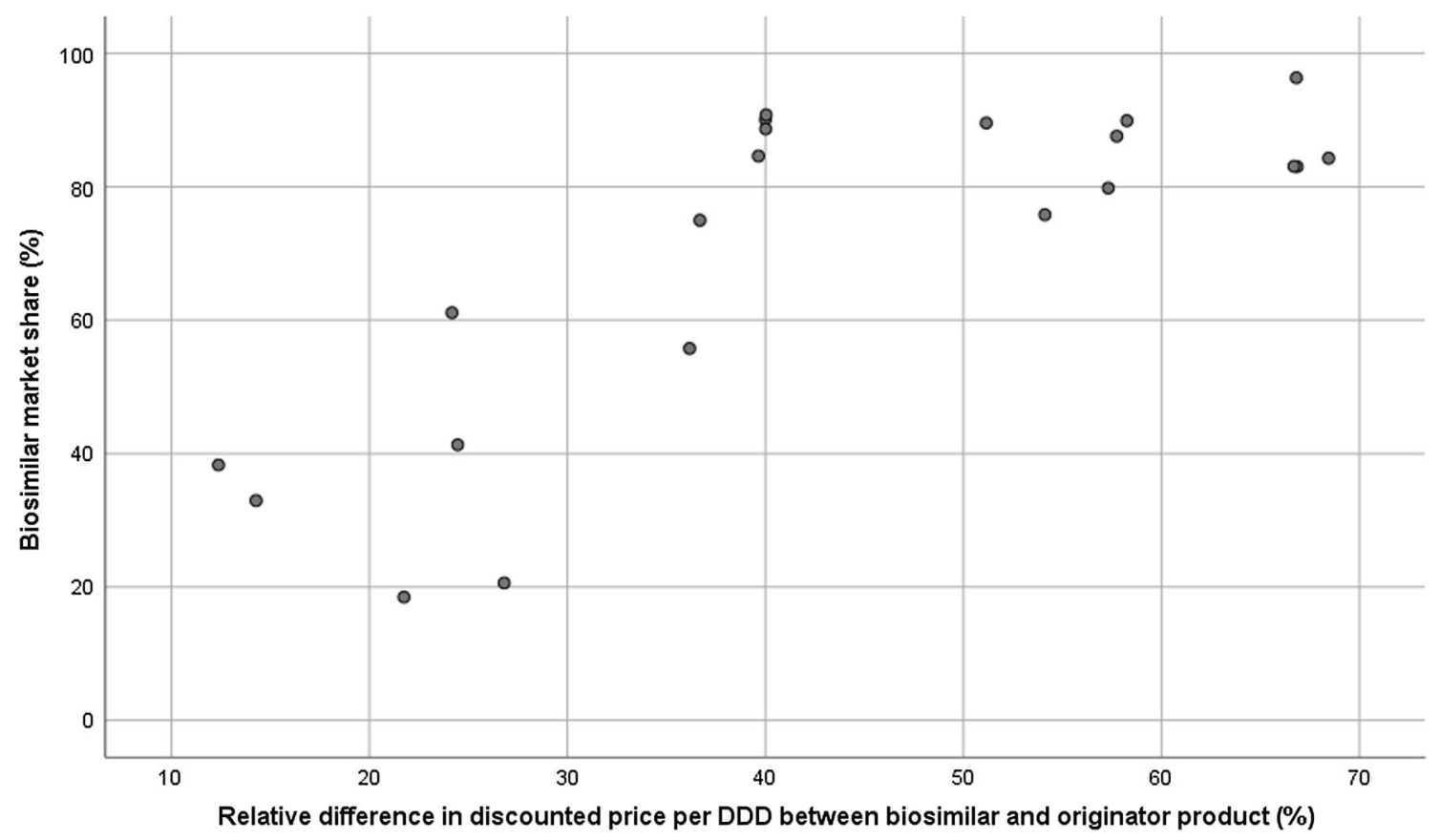

Fig. 2 Scatterplot of market shares of the infliximab biosimilar in the 21 Swedish counties in 2017 (outcome variable) and the relative difference in discounted price per defined daily dose (DDD) of the biosimilar relative to the originator product (covariate)

Simple linear regression analysis of data from 2017 revealed that $59 \%$ of the variability in biosimilar market shares between Swedish counties was explained by the relative difference in discounted price between the biosimilar and the originator product $(\mathrm{p} \leq 0.001)$. Multiple regression models combining the relative difference in cost with other independent variables were analysed but did not further explain the variations. Furthermore, a logit transformation of the outcome variable (biosimilar market share) did not influence the check of assumptions or results.

A linear relationship provides a reasonable approximation when examining the scatterplot of the biosimilar market share and the relative difference in discounted price between the biosimilar and the originator product (Fig. 2), although other relationships may be applicable. However, building a predictive model was not the purpose of this study, rather it was to demonstrate the influence of the primary driver. When visually analysed, a positive non-linear relationship can be seen, where the biosimilar market share rises when the relative difference in discounted price per DDD of the biosimilar versus the originator product in a county increases. This relationship then reaches a maximum: biosimilar market shares in counties exceed $76 \%$ from a threshold of a $40 \%$ difference in discounted price per DDD or more. When plotted as the absolute price difference, a difference of 50 Swedish kronor (SEK) per DDD ( €5 per DDD) led to high biosimilar market shares (76-96\%).
In addition to biosimilar market shares, we also analysed discounted prices per DDD. In quarter four of 2017, the discounted price per DDD of the originator ranged from SEK59 per DDD in Västra Götaland to SEK191 per DDD in Stockholm. The discounted price per DDD of the originator increased in Stockholm in quarter one of 2017, after loss of the single-winner tender on infliximab. In Västra Götaland, the originator product was priced at the same price level as the biosimilar. In 2017, a larger variation between counties was observed in the discounted price per DDD of the originator product (SEK69-190 per DDD) than for the biosimilar (SEK59-83 per DDD).

The average discounted price per DDD of infliximab in all counties decreased from SEK202 per DDD in 2012 to SEK173 per DDD in 2014 (the year before the entry of the biosimilar) and to SEK76 per DDD in 2017. Overall, in Sweden, the volume of infliximab (DDDs) increased 54\% from quarter two of 2012 to quarter four of 2017 (compound annual growth rate of $8 \%$ ), with more rapid escalation after the entry of the biosimilar in quarter one of 2015 (Fig. 3). Interviewees indicated that the increase in volume of infliximab could possibly be attributed to a lower threshold at which treatment is initiated (due to elimination of the price obstacle but also fewer concerns about the safety of biologicals now they have been on the market for some time), increased dosing now that prices have decreased, and more treatment-naïve patients receiving products for which a biosimilar exists. In Skåne, treatment of a patient with an expensive medicine requires 
Fig. 3 Volume evolution (in defined daily doses) of infliximab in Sweden from quarter two of 2012 to quarter four of 2017

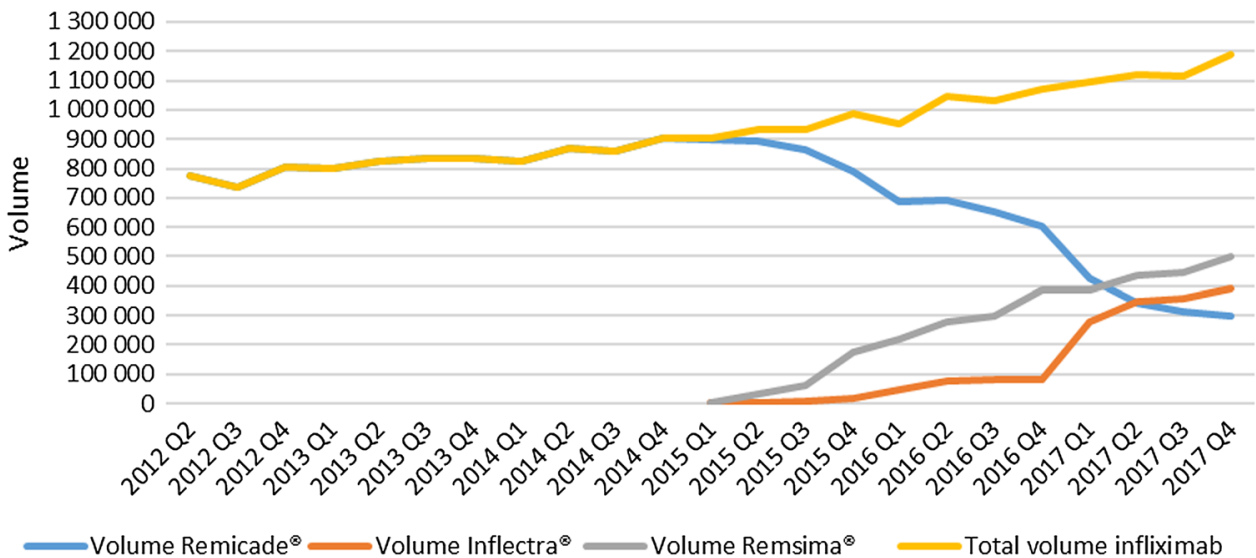

consensus from two physicians. Lowered prices can therefore lead to increased autonomy in prescribing.

\subsection{Local Policy Measures and Practices in a Selection of Counties}

\subsubsection{General Observations on the Swedish Healthcare Market}

TNF $\alpha$ inhibitors are available to patients in all counties, but differences might be seen in the threshold of initiation of therapy with biological medicines [7]. TNF $\alpha$ inhibitors are mainly prescribed by specialists, e.g. rheumatologists, dermatologists and gastroenterologists, who also bear responsibility for switching from the originator biological to the biosimilar [9]. On a national level, no pressure has ever been applied to switch between originator and biosimilar products. Reimbursement criteria are more binding, but adherence to these criteria is not checked with the individual counties. In general, physicians in Sweden accept biosimilars and have now accepted that the first switch is fine.

During the interviews, we observed that physicians in Sweden seem to have an altruistic attitude and are aware of cost increases with innovative medicines. To begin with, this might be a consequence of the perceived high level of trust that Swedish physicians have of the European Medicines Agency and the healthcare system in Sweden. In addition, this altruistic attitude may be enabled by the way the healthcare system is organised in relatively small regions, where you can see how the money saved is used in other therapeutic areas, and the relatively low number of specialists in an area allows good communication on new guidelines and market dynamics. In Skåne, rheumatologists were advised of the county council's decision to switch all patients receiving the originator product to the biosimilar, and the decision was explained. Furthermore, prescribing behaviour was monitored to check whether recommendations were followed (although they are not binding). Physicians were individually encouraged to adhere to the agreements.

It appeared that counties leverage biosimilars to lower drug costs and make room for other patients to access treatment, thus focusing on sustainability and not just on savings. The priority for the drug budget is to make room for segments that are increasing more than others, e.g., oncology. It was acknowledged that more could be done in terms of competition and short-term savings but that this would probably upset physicians and patient organisations. Moreover, aggressive price competition may undermine the long-term sustainability of a competitive market.

Interviewees identified several drivers of the decision making around using originator or biosimilar infliximab, which can differ between counties and therefore affect regional variations. These drivers are the absolute/relative difference in discounted price between the originator and biosimilar, the opinion of key opinion leaders or the preferences of the clinic head, local guidelines and initiatives in the hospital, and whose budget is affected.

As the organisation of the local healthcare system, financial streams and the level at which you have budget responsibilities differ between counties, it was difficult to determine who benefited from potential cost savings. Gainsharing, where savings are shared between the payer and the hospital or prescribing physician, was suggested as a factor influencing market dynamics. In Skåne, Stockholm and Västra Götaland, savings that are made via leveraging competition of biosimilars stay within the drug budget. As budgets for hospital medicines are adjusted every year, it may be that, in the long term, the county councils benefit from savings. In Skåne, approximately half of the savings return to the hospital departments affected, e.g. for new products such as vedolizumab, and half can be used in other therapeutic areas. The hospital budget is adjusted to the predicted need. The interviewees felt loyal to the system as they always received the budget they needed when using it as efficiently as possible. In Stockholm, hospitals must pay for drugs used in 
Table 2 Selection of characteristics of the infliximab market in the interviewed counties. Figures for quarter four of 2017

\begin{tabular}{|c|c|c|c|c|c|}
\hline County & Tender with biosimilar & $\begin{array}{l}\text { Biosimilar } \\
\text { uptake }(\%)\end{array}$ & $\begin{array}{l}\text { Difference }(\%) \text { in } \\
\text { discounted price/ } \\
\text { DDD }\end{array}$ & $\begin{array}{l}\text { Discounted price } \\
\text { (SEK)/DDD cheapest } \\
\text { product }\end{array}$ & $\begin{array}{l}\text { Discounted price } \\
\text { (SEK)/DDD } \\
\text { infliximab }\end{array}$ \\
\hline Skåne & $\begin{array}{l}\text { Multi-winner (July 2015): Remsima }{ }^{\circledR} \\
\text { cheapest }\end{array}$ & 92 & -47 & 60 & 64 \\
\hline Stockholm & $\begin{array}{l}\text { Single winner (Jan 2017): Inflectra }{ }^{\circledR} \text { cheap- } \\
\text { est }\end{array}$ & 86 & -69 & 59 & 78 \\
\hline Västra Götaland & $\begin{array}{l}\text { Multi-winner (Feb 2017): Inflectra }{ }^{\circledR} \text { and } \\
\text { Remicade }^{\circledR} \text { same price }\end{array}$ & 47 & 1 & 59 & 59 \\
\hline
\end{tabular}

Difference in discounted price/DDD: difference in discounted price per DDD of the biosimilar relative to the discounted price of the originator product in quarter four of 2017

$D D D$ defined daily dose

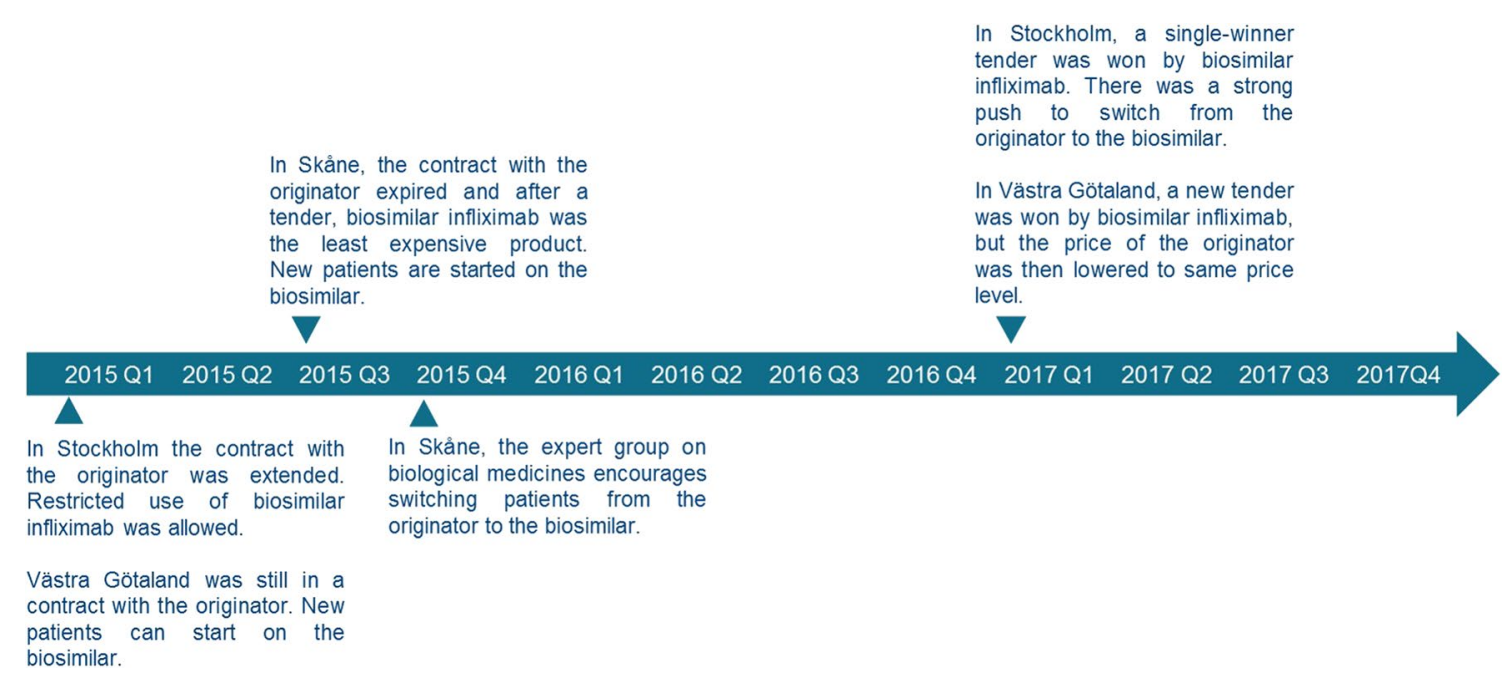

Fig. 4 Different approaches of interviewed counties (Skåne, Stockholm, Västra Götaland) to leverage competition from biosimilar infliximab

the inpatient setting from their own budget and can keep savings for use in other departments. In Västra Götaland, savings would remain in the hospital in the short term but their budget may be decreased in the long term.

\subsubsection{County Approaches to the Entry of Infliximab Biosimilars}

Table 2 presents some characteristics of the infliximab market in the interviewed counties. The intention of the various counties in the tender process is to achieve a low price per DDD of infliximab. Figure 4 shows the different approaches taken by counties identified during the local interviews, i.e., a rapid switch to the biosimilar (Skåne), a delayed switch to the biosimilar (Stockholm), or no switch to the biosimilar when a favourable price on the originator product could be obtained (Västra Götaland). These approaches led to discounted prices for infliximab of SEK64, SEK78, and SEK59 per DDD, respectively, with a national mean of SEK70 per
DDD and a range of SEK59-106 per DDD, in quarter four of 2017. In Stockholm, although the discounted price per DDD of the biosimilar is low (SEK59 per DDD) and the biosimilar market share is high (86\%), the use of the high-priced originator in few cases has led to an overall discounted price per DDD of infliximab that is higher than in Skåne or Västra Götaland.

According to the interviewees, the main criterion for awarding a contract is the price of the biosimilar or originator, since these products will not differentiate in terms of injection equipment and other criteria such as guaranteed delivery and good manufacturing practices. The duration of a tender is usually 2 years with an option to extend. As physicians do not like to switch every year, they prefer the tender duration to be as long as possible. Contracts of shorter duration can also be agreed when market conditions are expected to change in the near future, such as with the introduction of a new competitor. Some counties offer tenders in which companies can adjust prices during the tender 
duration. In all three interviewed counties, guidelines recommended that the most cost-effective treatment should be chosen when initiating treatment for a new patient.

In Skåne, since 2014 (before the biosimilar entered the market), naïve patients were increasingly initiated on infliximab instead of other TNF $\alpha$ inhibitors. In early 2015, when biosimilars to infliximab were launched on the market, Skåne was locked in a contract with the originator product until July 2015. It was decided not to switch patients at that time but to start using the biosimilar in new patients. After 6 months, when preliminary information became available on the NOR-SWITCH trial (a comparative trial between patients switched from originator infliximab to biosimilar infliximab, CT-P13, and patients who maintained treatment with originator infliximab, funded by the Norwegian Ministry of Health; full results were published in 2017 [26]) and after consultation with colleagues, physicians in the expert group on biologicals decided to switch patients from the originator product to the less expensive biosimilar to save money. Key opinion leaders in gastroenterology supported this and had personal connections with colleagues involved in the NOR-SWITCH study.

Stockholm was also locked in a contract for the originator product when biosimilar infliximab entered the market. The Stockholm county council decided to move slowly with the first infliximab biosimilars to gain experience and create trust among physicians and patients so as to move quicker on future biosimilars. Therefore, the existing contract on the originator product was extended for another 2 years (until January 2017). However, a decrease in the price of the originator product was agreed to reflect competition in the market, and a clause was included in the contract that allowed restricted use of the biosimilar. During 2015-2016, while Stockholm was still in the tender contract with the originator product, uptake of the biosimilar was higher than first expected (23\%).

Västra Götaland also had a contract for the originator product (from 2014 to January 2017) when biosimilar infliximab was introduced to the Swedish market. Within the contract, there was room for using other similar products, and the drug and therapeutics committee recommended that up to one-third of new patients could start with a biosimilar, since Remsima ${ }^{\circledR}$ was less expensive.

In a multi-winner tender in Skåne in July 2015, the biosimilar was the least expensive product. In October 2015, the expert group on biological medicines strongly encouraged prescribing of the biosimilar, which translated into an increased volume of biosimilar infliximab. This quick uptake of the biosimilar was attributed to good connections between the different hospital departments and consultation with the rheumatology patient organisation. In Stockholm, more experience was initially gained with the biosimilar before a new tender was organised. In January 2017, a single-winner tender on infliximab was won by infliximab biosimilar Inflectra ${ }^{\circledR}$, and all patients were switched, increasing the biosimilar market share from $23 \%$ in quarter four of 2016 to $80 \%$ in quarter one of 2017. All involved stakeholders were included in making this decision. In February 2017, Västra Götaland issued a new tender with a view to gaining a low price on both the originator product and biosimilar infliximab. Inflectra ${ }^{\circledR}$ was the least expensive product; however, as the price of the originator product was subsequently lowered to match that of the biosimilar, there has never been an economic incentive for switching. First, physicians in Västra Götaland were locked in the contract for the originator product, then the price of the originator and the biosimilar was the same; in addition, they were not in favour of switching in early 2017.

When the biosimilar was the least expensive product in the tender process, active switching of patients from the originator product to the biosimilar was initiated in Skåne and Stockholm. In Skåne, different approaches for the different therapeutic indications were apparent. In rheumatology, either the physician informed the patient of a switch in treatment or a letter was given to the patient explaining what a biosimilar was, that it is as safe and effective as the originator, and what the savings would be used for (e.g. to switch back if some patients experienced problems with the biosimilar). Patients were then switched at the next appointment (approximately 6 weeks later). In gastroenterology, a letter was given to patients at the outpatient unit; after receiving it, patients could talk to a nurse or ask further questions to their physician. Most patients had a positive attitude towards this initiative and were immediately switched. Dermatology patients also received a letter at the hospital followed by an immediate switch. In Stockholm, all patients with an appointment in November or December 2016 were told that they would receive the biosimilar during the next visit (January 2017). In Västra Götaland, none of the patients were switched. Only new patients were started on the biosimilar to spread the risk of, for example, delivery problems over different products. Since the NOR-SWITCH study [26], physicians in Västra Götaland accept switching once in stable and well-informed patients but do not support multiple switching. A good incentive, such as a long-term substantial difference in price, would convince them to switch and overcome the associated administrative work. A good price on the originator product, as this was long their product of first choice, explains the limited use of infliximab biosimilars in Västra Götaland.

\section{Discussion}

Many publications only provide an overview of existing policy measures on biosimilars [27-29], therefore several authors recommended that the impact of implemented policies and practices be studied quantitatively [27, 30]. In 
Table 3 Identified drivers and enablers in the Swedish healthcare system to leverage competition from biosimilars

\begin{tabular}{lll}
\hline Drivers & & Enablers \\
\hline Quantitative study & Qualitative study & \\
\hline $\begin{array}{lll}\text { The difference in discounted price per DDD between the bio- } \\
\text { similar and the originator product (potential savings) }\end{array}$ & $\begin{array}{l}\text { The difference in discounted price per } \\
\text { DDD }\end{array}$ & $\begin{array}{l}\text { A multi-stakeholder approach } \\
\text { An altruistic attitude } \\
\text { Key opinion leaders }\end{array}$ \\
& Local guidelines & Good communication with colleagues \\
& Gainsharing &
\end{tabular}

$D D D$ defined daily dose

response, this article quantifies the relation between the biosimilar market share and the net discount of the biosimilar relative to the price of the originator product. Furthermore, it provides a descriptive analysis of the evolution of market data of originator and biosimilar infliximab in the different counties of Sweden. Clarification of trends observed in market dynamics was obtained from literature and from local interviews. Table 3 summarizes the identified drivers and enablers in the Swedish healthcare system to leverage competition from biosimilars. Both the quantitative and the qualitative study revealed that increasing differences in discounted price between the biosimilar and originator product would favour the use of the least expensive product, indicating that potential savings associated with the biosimilar would incentivise stakeholders to switch from the originator product to the biosimilar. In addition, preferences of key opinion leaders also play a role in decision making and implementation, as do local guidelines and how savings will be distributed among stakeholders. Enabling factors such as a multi-stakeholder approach, an altruistic attitude of prescribers and good communication between colleagues facilitates implementation of outcomes of tender contracts and guidelines. Earlier research also noted the influence of the altruistic attitude of the Swedish population on perceptions and behaviour [31, 32].

\subsection{Added Value of This Study}

To the best of our knowledge, this is one of the first studies to evaluate regional variations to study the effect of biosimilar policies and initiatives on market dynamics, with Sweden and its counties as a case study. Neovius et al. [7] studied regional variations in Sweden for sales per capita of originator TNF $\alpha$ inhibitors. In contrast, our study includes competition by the introduction of biosimilars. Other studies also reported regional variations in biosimilar uptake in a country $[9,11,13,14]$ but did not explicitly link this to implemented policies or derived driving factors influencing the market dynamics of TNF $\alpha$ inhibitors. A study by Rémuzat et al. [33] followed a similar methodology to ours when they performed a regression model analysis based on a literature review of incentive policies and analysis of biosimilar market data in ten EU member states to identify drivers of biosimilar uptake in Europe. Our study on regional variations in one country, Sweden, combines a literature review and database analysis with face-to-face discussions to explain findings. Additionally, we used net prices for the hospital market, leading to substantially different outcomes. Our study indicated a strong relationship between the biosimilar market share and the net discount of the biosimilar relative to the price of the originator product, whereas Rémuzat et al. [33] found that the biosimilar listed price discount over the price of the originator product was not associated with biosimilar uptake. This emphasises the importance of working with actual prices rather than list prices in determining factors driving decision making.

\subsection{Price Effects}

This study also showed that biosimilars for infliximab created competition in the infliximab market. Overall, we observed a decrease in the discounted price per DDD of infliximab in all counties since the introduction of the biosimilar and a concomitant increase in patients being treated with infliximab. This will benefit patients, as early treatment with biologicals will lead to improved clinical responses [34-36]. The price of a product plays a major role in choice of treatment, as illustrated by high biosimilar market shares of infliximab with increasing differences in the discounted price of the biosimilar relative to the originator product. In Västra Götaland, the market share of the biosimilar increased since its entry in quarter two of 2015 as a result of a lower price. As the price of the originator and biosimilar were set at the same level in February 2017, this leads us to expect that the biosimilar market share will not increase further during this tender period. Being the first biosimilar on the market will be an advantage, as it will be harder for subsequent biosimilars to match a similar absolute price difference with the product currently used in order to offer an incentive for counties to switch between biosimilars. It is unclear from this study what difference in price is needed to switch back from the biosimilar to the originator or to a second biosimilar, as this could not be examined. 


\subsection{Competition and Market Sustainability}

It has been illustrated that lowering drug costs is not just about uptake of the biosimilar but also about leveraging competition to alter market dynamics between biosimilar and originator products, and associated prices. The different tender groups in Sweden make the market sustainable for both originator and biosimilar infliximab. On the one hand, tenders being organised at a county level offers an advantage in that a manufacturer who does not win the bid in one county has an incentive to stay on the market by participating in tenders in other counties. On the other hand, the limited market size of individual counties may restrict the price reductions offered by manufacturers in contrast with national tenders (such as, for example, in Norway [37]). A concern related to the tender system is the sustainability of discounts. Although all counties want a large reduction in price, if prices are pushed to the limit, there is a risk that companies will withdraw their product from the market.

In contrast to Sweden, where existing contracts can hinder market access of biosimilars, the Italian procurement law of December 2016 established a new framework for procurement of off-patent biological products. In this framework, based on therapeutic equivalence, biosimilars and originator products will compete in the same tender [38]. Regional health authorities must open existing contracts within 60 days after launch of the biosimilar to create competition [39]. When more than three competitors are on the market, a multi-winner regional tender is organised, after which physicians must prescribe one of the top three preferred products, except when they deem treatment of the patient should not be interrupted. This system allows immediate and direct competition between biosimilars and originator products, with promotion of the least expensive products, while maintaining physicians' prescribing freedom. However, an advantage of the Swedish system is the increased autonomy in making decisions on a new tender, allowing the opinions of all stakeholders on the use of biosimilars and switching from the originator to the biosimilar to be aligned first.

\subsection{Influences on Prescribing Behaviour of Specialists}

The current thinking of Swedish specialists prescribing TNF $\alpha$ inhibitors seems to be in line with the position statement of the Swedish Medical Products Agency, which deems treatment with a biosimilar uncontroversial in treatment-naïve patients and believes no barriers exist to switch stable, well-informed patients from the originator biological to the biosimilar $[9,40]$. The position statement also indicates that more data are needed on multiple switching. To provide information from independent third parties, the Dental and Pharmaceutical Benefits Agency and the Medical
Products Agency combined efforts to educate stakeholders [9]. However, as national authorities can only recommend but the individual counties decide which products to use, this might undermine the objective of providing equal care to patients $[15,16]$.

On the other hand, decentralising the responsibility for providing healthcare to the county councils has the advantage that specialists and other healthcare professionals often know each other and therefore tend to follow recommendations quicker than if a national organisation announces guidance on prescribing. It has been shown that activities of the kind performed by the drug and therapeutics committees have more impact on prescribing patterns when organised at a local level and built on personal relations [10]. An increased awareness by stakeholders on the use of taxes might have contributed to the system of solidarity and the altruistic attitude of physicians towards using the savings in other therapeutic areas.

\subsection{Verification of Identified Drivers}

Earlier research on uptake of new medicines also identified the importance of communication between colleagues and the influence of key opinion leaders [41, 42]. Chauhan et al. [41] concluded that the impact of clinical guidelines on uptake of new medicines has been variable, possibly due to concerns of the evidence-based nature of the guidelines and a perceived loss of autonomy by physicians. Research on the high adherence of physicians to the recommendations of the Wise List in Stockholm, which also includes guidance on the use of TNF $\alpha$ inhibitors, explained that a transparent development process and a multi-stakeholder approach including key opinion leaders is used to come up with sound evidencebased prescribing guidance [25]. Other contributing factors that are mentioned are a good communication strategy, feedback to physicians, education and financial incentives.

Given that healthcare systems tend to be complex and vary between countries, it may not be possible to extrapolate our findings directly to other countries. However, we believe some general drivers can be identified that can be applied in other countries to support a sustainable biological market with competition from biosimilars. Where tendering is a factor related to the system, contextual factors can be more easily adapted. Introduction of guidance on prescribing and follow-up on adherence of these guidelines can be one measure. A drug utilisation study in a region in Italy showed that guidance on prescribing granulocyte colony-stimulating factors led to an increased uptake of the less expensive biosimilar [43]. Other measures might be consultation between stakeholders, a focus on a multi-stakeholder approach in decision making and implementation, and the introduction of gainsharing arrangements. Furthermore, experts in their 
field that push for the least expensive treatment option might trigger physicians to reflect on their prescribing behaviour.

\subsection{Limitations}

This study is subject to a number of limitations. First, we did not interview representatives from all 21 counties, impacting the generalizability of outcomes for Sweden. As the three interviewed counties represent $>50 \%$ of the population and $>50 \%$ of the use (volume) of infliximab, this will probably not considerably affect our results. Second, this study investigated only the biosimilar TNF $\alpha$ market, not the total biosimilar market. Also, no (biological) therapies other than TNF $\alpha$ inhibitors were considered for treatment of shared indications, e.g., abatacept, rituximab, tocilizumab. The largest shifts in market dynamics are expected to happen within the class of TNF $\alpha$ inhibitors. Third, regression analysis can serve to determine the influence of one variable on the biosimilar market share or to explain as much of the variation as possible. Statistical reasons, i.e. a limited number of observations, correlation between independent variables, non-linearity of the data, led us to choose a model describing the primary driver, i.e. the difference in price between the biosimilar and the originator product, accounting for net prices instead of list prices.

\subsection{Future Research}

Future research could focus on regional variations in other European countries (e.g. Spain, Italy, Germany, the UK) to investigate whether the drivers identified in this study are also applicable to other healthcare systems. A regression model could then be developed with more universal drivers predicting a high or low biosimilar market share, and factors that lead to decreases in drug costs could be identified. Furthermore, factors affecting regional variations in Sweden in healthcare services provided to residents could be further investigated to streamline best practices.

\section{Conclusion}

This study has shown that variation in biosimilar infliximab market shares between Swedish counties is largely explained by the relative difference in discounted price between biosimilar and originator product. Visual inspection of the data suggests high uptake of the biosimilar upward of $40 \%$ difference in discounted price. Counties employed different strategies to leverage price reductions generated by biosimilar competition. The discounted price per DDD of infliximab reduced in all counties following market entry of biosimilars; this was achieved either with a lower price for biosimilar infliximab or with a large price reduction for the originator product consequent to biosimilar competition.

Treatment costs associated with infliximab ranged from SEK59 to SEK106 per DDD in quarter four of 2017, implying that some counties employed more effective approaches than others to reduce prices. Factors influencing decision making may vary between counties, e.g. a large price difference between the biosimilar and the originator product, local guidelines and follow-up on adherence, presence of key opinion leaders, a head of clinic who is strongly involved in the discussion, awareness of physicians on the high costs of biological treatment, and the possibility of keeping savings and using them to treat more patients or sustain budgets in other therapeutic areas. The success of these drivers should be seen in relation to the presence of enabling factors in the Swedish hospital setting, such as a multi-stakeholder approach, an altruistic attitude of prescribers, and good communication between specialists prescribing infliximab.

Acknowledgements The authors thank Karl Arnberg and Gustaf Befrits, in their respective functions at the Dental and Pharmaceutical Benefits Agency and the Stockholm County Council, for sharing insights into the Swedish healthcare market and market dynamics on originator and biosimilar infliximab, and their valuable feedback on the manuscript. The authors also thank Björn Wettermark for critical review of the manuscript. In addition, the authors acknowledge the Leuven Biostatistics and Statistical Bioinformatics Centre for statistical advice during the project.

Author Contributions IH, AV, SS, PT and EM developed the idea for and were involved in the design of this study. EM and AV were involved in data collection. EM drafted the initial version of the manuscript. IH, AV, SS, PT, and PD critically reviewed the manuscript. All authors read and approved the final manuscript.

\section{Compliance with Ethical Standards}

Funding This study was supported by KU Leuven and by the Fund on Market Analysis of Biologics and Biosimilars following Loss of Exclusivity (MABEL).

Conflict of interest SS, IH and AV have conducted biosimilar research sponsored by Hospira (now Pfizer). SS was involved in a stakeholder roundtable on biosimilars sponsored by Amgen, Pfizer and MSD and has participated in an advisory board meeting for Pfizer. SS currently works with Pfizer, and works with Celltrion as a consultant to carry out biosimilar research. AV is involved in consulting, advisory work and speaking engagements for a number of companies, including AbbVie, Accord, Amgen, Biogen, EGA, Pfizer/Hospira, Mundipharma, Roche and Sandoz. PD participated in advisory board meetings for AbbVie, Amgen and Hospira and is on the speakers' bureaux of AbbVie, Celltrion, Hospira, Merck Serono and Roche. PT is employed by IQVIATM. EM has no conflicts of interest that are directly relevant to the content of this article. The statements, findings, conclusions, views, and opinions contained and expressed herein are not necessarily those of IQVIA $^{\mathrm{TM}}$ or any of its affiliated or subsidiary entities. 
Open Access This article is distributed under the terms of the Creative Commons Attribution-NonCommercial 4.0 International License (http://creativecommons.org/licenses/by-nc/4.0/), which permits any noncommercial use, distribution, and reproduction in any medium, provided you give appropriate credit to the original author(s) and the source, provide a link to the Creative Commons license, and indicate if changes were made.

\section{References}

1. Geynisman DM, De Velasco G, Sewell KL, Jacobs I. Biosimilar biologic drugs: a new frontier in medical care. Postgrad Med. 2017;129(4):460-70. https://doi.org/10.1080/00325 481.2017.1311196.

2. Lis K, Kuzawinska O, Balkowiec-Iskra E. Tumor necrosis factor inhibitors—state of knowledge. Arch Med Sci. 2014;10(6):117585. https://doi.org/10.5114/aoms.2014.47827.

3. 2017 Sales of Recombinant Therapeutic Antibodies \& Proteins. Weikersheim: La Merie Publishing; 2018.

4. EMA. Download medicine data. European Medicines Agency; 2019. https://www.ema.europa.eu/en/medicines/download-medic ine-data. Accessed Mar 2019.

5. Top 8 blockbuster biologicals 2013. 2014. http://www.gabionline .net/Biosimilars/General/Top-8-blockbuster-biologicals-2013. Accessed 24 Sep 2015.

6. The Impact of Biosimilar Competition in Europe. London: Quintiles. IMS2017.

7. Neovius M, Sundstrom A, Simard J, Wettermark B, Cars T, Feltelius N, et al. Small-area variations in sales of TNF inhibitors in Sweden between 2000 and 2009. Scand J Rheumatol. 2010;40(1):8-15. https://doi.org/10.3109/03009742.2010.493895.

8. Analys av marknaden för biologiska läkemedel med konkurrens av biosimilarer [Analysis of the biologics market with competition of biosimilars]. Tandvårds- och läkemedelsförmånsverket. 2016.

9. Producentoberoende information om biosimilarer [Producerindependent information on biosimilars]. Tandvårds- och läkemedelsförmånsverket2017.

10. Arnlind MH, Wettermark B, Nokela M, Hjemdahl P, Rehnberg C, Jonsson EW. Regional variation and adherence to guidelines for drug treatment of asthma. Eur J Clin Pharmacol. 2010;66(2):18798. https://doi.org/10.1007/s00228-009-0731-7.

11. Alnahar S, Elliott RA, Smith MD. Biosimilar uptake by British local formularies: a cross sectional study. Int J Clin Pharm. 2017;39(5):1055-60. https://doi.org/10.1007/s11096-017-0523-6.

12. Flume M. Biosimilars-Best practice models in Germany. 15th Biosimilar Medicines conference (Medicines for Europe); London. 2017.

13. Marciano I, Ingrasciotta Y, Giorgianni F, Bolcato J, Chinellato A, Pirolo R, et al. How did the introduction of biosimilar filgrastim influence the prescribing pattern of granulocyte colonystimulating factors? Results from a multicentre, population-based study, from five Italian centres in the years 2009-2014. BioDrugs. 2016;30(4):295-306. https://doi.org/10.1007/s40259-016-0175-4.

14. Marciano I, Ingrasciotta Y, Giorgianni F, Ientile V, Chinellato A, Tari DU, et al. Pattern of use of biosimilar and originator somatropin in Italy: a population-based multiple databases study during the years 2009-2014. Front Endocrinol (Lausanne). 2018;9:95. https://doi.org/10.3389/fendo.2018.00095.

15. Hälso- och sjukvårdslag (1982:763) [The Health and Medical Service Act]. Sveriges Riksdag. 1982. https://www.riksdagen.se/ sv/dokument-lagar/dokument/svensk-forfattningssamling/halso -och-sjukvardslag-1982763_sfs-1982-763. Accessed 05/2018.

16. Hälso- och sjukvårdslag (2017:30) [The Health and Medical Service Act]. Sveriges Riksdag. 2017. https://www.riksdagen.se/sv/ dokument-lagar/dokument/svensk-forfattningssamling/halso-ochsjukvardslag_sfs-2017-30. Accessed 05/2018.

17. Jansson S, Anell A. The impact of decentralised drug-budgets in Sweden-a survey of physicians' attitudes towards costs and cost-effectiveness. Health Policy. 2006;76(3):299-311. https:// doi.org/10.1016/j.healthpol.2005.06.002.

18. Lag (1996:1157) om läkemedelskommittéer [Law on drug committees]. Sveriges Riksdag. 1996. https://www.riksdagen.se/ sv/dokument-lagar/dokument/svensk-forfattningssamling/lag19961157-om-lakemedelskommitteer_sfs-1996-1157. Accessed 05/2018.

19. Sjoqvist F, Bergman U, Dahl M, Gustafsson LL, Hensjo L. Drug and therapeutics committees: a swedish experience. WHO Drug Inf. 2002;16(3):207-13.

20. Pontén J, Rönnholm G, Skiöld P. PPRI pharma profile Sweden 2017. Stockholm: The Dental and Pharmaceutical Benefits Agency; 2017.

21. Eriksson I, Wettermark B, Persson M, Edstrom M, Godman B, Lindhe A, et al. The early awareness and alert system in Sweden: history and current status. Front Pharmacol. 2017;8:674. https://doi.org/10.3389/fphar.2017.00674.

22. In English-Tandvårds-Läkemedelförmånsverket. Tandvårdsoch läkemedelsförmånsverket. 2018. https://www.tlv.se/in-engli sh.html. Accessed 052018.

23. IQVIA Sweden AB consumption data sourced from eHm.

24. IBM. IBM SPSS Statistics for Windows. 25.0 ed. Armonk: IBM Corp.; 2017.

25. Eriksen J, Gustafsson LL, Ateva K, Bastholm-Rahmner P, Ovesjo ML, Jirlow M, et al. High adherence to the 'Wise List' treatment recommendations in Stockholm: a 15-year retrospective review of a multifaceted approach promoting rational use of medicines. BMJ Open. 2017;7(4):e014345. https://doi. org/10.1136/bmjopen-2016-014345.

26. Jorgensen KK, Olsen IC, Goll GL, Lorentzen M, Bolstad N, Haavardsholm EA et al. Switching from originator infliximab to biosimilar CT-P13 compared with maintained treatment with originator infliximab (NOR-SWITCH): a 52-week, randomised, double-blind, non-inferiority trial. Lancet. 2017. https://doi. org/10.1016/s0140-6736(17)30068-5.

27. Moorkens E, Vulto AG, Huys I, Dylst P, Godman B, Keuerleber $\mathrm{S}$, et al. Policies for biosimilar uptake in Europe: an overview. PLoS One. 2017;12(12):e0190147. https://doi.org/10.1371/ journal.pone.0190147.

28. Renwick MJ, Smolina K, Gladstone EJ, Weymann D, Morgan SG. Postmarket policy considerations for biosimilar oncology drugs. Lancet Oncol. 2016;17(1):e31-8. https://doi.org/10.1016/ S1470-2045(15)00381-2.

29. Rémuzat C, Kapuśniak A, Caban A, Ionescu D, Radière G, Mendoza $\mathrm{C}$ et al. Supply-side and demand-side policies for biosimilars: an overview in 10 European member states. J Mark Access Health Policy. 2017. https://doi.org/10.1080/20016 689.2017.1307315.

30. Swartenbroekx N, Farfan P, Espin J, Gerkens S. Incentives for market penetration of biosimilars in Belgium and in five European countries. J Pharm Belg. 2014;4:36-46.

31. Ancillotti M, Eriksson S, Veldwijk J, Nihlen Fahlquist J, Andersson DI, Godskesen T. Public awareness and individual responsibility needed for judicious use of antibiotics: a qualitative study of public beliefs and perceptions. BMC Public Health. 2018;18(1):1153. https://doi.org/10.1186/s12889-018-6047-8.

32. Godskesen TM, Kihlbom U, Nordin K, Silen M, Nygren P. Differences in trial knowledge and motives for participation among cancer patients in phase 3 clinical trials. Eur J Cancer Care (Engl). 2016;25(3):516-23. https://doi.org/10.1111/ecc.12319.

33. Rémuzat C, Dorey J, Cristeau O, Ionescu D, Radiere G, Toumi $\mathrm{M}$. Key drivers for market penetration of biosimilars in Europe. 
J Mark Access Health Policy. 2017;5(1):1272308. https://doi. org/10.1080/20016689.2016.1272308.

34. St Clair EW, van der Heijde DM, Smolen JS, Maini RN, Bathon JM, Emery P, et al. Combination of infliximab and methotrexate therapy for early rheumatoid arthritis: a randomized, controlled trial. Arthritis Rheum. 2004;50(11):3432-43. https://doi. org/10.1002/art.20568.

35. Colombel JF, Sandborn WJ, Reinisch W, Mantzaris GJ, Kornbluth A, Rachmilewitz D, et al. Infliximab, azathioprine, or combination therapy for Crohn's disease. N Engl J Med. 2010;362(15):138395. https://doi.org/10.1056/NEJMoa0904492.

36. Baranauskaite A, Raffayova H, Kungurov NV, Kubanova A, Venalis A, Helmle L, et al. Infliximab plus methotrexate is superior to methotrexate alone in the treatment of psoriatic arthritis in methotrexate-naive patients: the RESPOND study. Ann Rheum Dis. 2012;71(4):541-8. https://doi.org/10.1136/ard.2011.152223.

37. Asbjørn M. Norway, biosimilars in different funding systems: what works? GaBi J. 2015;4(2):90-2. https://doi.org/10.5639/ gabij.2015.0402.018.

38. Dylst P. The 2017 market review -european biosimilar medicines markets-policy overview: medicines for Europe-Biosimilar Medicines Group. 2017.

39. Uda M, editor. The new Italian procurement law on off-patent biological medicines. 15th Biosimilar Medicines Conference (Medicines for Europe); 2017; London.
40. Biosimilar-äkemedelsverket/Swedish Medical Products Agency. Läkemedelsverket. 2017. https://lakemedelsverket.se/malgrupp/ Foretag/Lakemedel/Biologiska-lakemedel/Biosimilar/. Accessed 05/2018.

41. Chauhan D, Mason A. Factors affecting the uptake of new medicines in secondary care-a literature review. J Clin Pharm Ther. 2008;33(4):339-48. https://doi.org/10.111 1/j.1365-2710.2008.00925.x.

42. Lubloy A. Factors affecting the uptake of new medicines: a systematic literature review. BMC Health Serv Res. 2014;14:469. https://doi.org/10.1186/1472-6963-14-469.

43. Trotta F, Mayer F, Mecozzi A, Amato L, Addis A. Impact of guidance on the prescription patterns of G-CSFs for the prevention of febrile neutropenia following anticancer chemotherapy: a population-based utilization study in the Lazio region. BioDrugs. 2017;31(2):117-24. https://doi.org/10.1007/s40259-017-0214-9.

44. Johansson P, Befrits G, editors. Biosimilars in Sweden-national and regional perspective. 16th Biosimilar Medicines Conference; 2018; London.

45. Moorkens E, Simoens S, Troein P, Declerck P, Vulto AG, Huys I. Different policy measures and practices between Swedish counties influence market dynamics: Part 2-Biosimilar and originator etanercept in the outpatient setting. BioDrugs. 2019. https://doi. org/10.1007/s40259-019-00346-5. 